\title{
Russia in the International System: BRICS and the Eurasian Union
}

\author{
Marcela Mihaela Staniște \\ PhD Student, Doctoral School of International Relations and Security Studies \\ Faculty of History and Philosophy, Babes-Bolyai University, Cluj-Napoca
}

\begin{abstract}
The $21^{s t}$ century is marked by a series of events and changes in the international system. The dominance of the US is challenged by the rise of emerging powers and their external policy objectives of obtaining a greater role in the formulation of international politics and in the main international institutions. This paper will focus on one of the countries in the emerging powers group, maybe the most controverted one, Russia. Many observers consider that Russia isn't an emerging power and can't be seen as a great power any more. Based on the theory of interdependence this papers aims to analyze if the BRICS group and The Eurasian Union can be considered tools for the development of Russian power. In an interdependent world, Russia already responds to Western economic sanctions by deepening relations with the BRICS countries and within the BRICS group and also by making efforts to support the Eurasian Union, one of the major external policy objectives of Vladimir Putin.
\end{abstract}

Keywords: power, interdependence, international system, BRICS, the Eurasian Union

\section{Introduction}

The events of the $20^{\text {th }}$ and $21^{\text {st }}$ century changed the world order and the international actors have to deal with different types of issues and challenges. Russia was one of the two superpowers of the bipolar system during the Cold War, but after the dissolution of the Soviet Union and the 1998 economic crisis had to struggle to regain its status of great power. The rise of the oil prices generated economic growth and in 2001, Russia was considered one of the four largest emerging economies by Jim O'Neill, a Goldman Sachs analyst. At the beginning of the $21^{\text {st }}$ century the country's economy was growing, unfortunately only based its on natural resources and gas dependent economy.

Now, the country's status of great power is disputed and the economic prognosis aren't too optimistic. This paper will begin by describing the historical context of Russia in the last two decades and the current political and economic crisis. In the second part of the paper we will analyse Russia's participation in the group of emerging countries (BRICS) and its plan to regain influence on the former Soviet republics (The Eurasian Economic Union). After the Ukrainian Crisis the western countries imposed economic sanctions and made efforts to isolate Russia in international politics. The aim of the paper is to analyse if the BRICS and The Eurasian Union can be considered tools for the development of Russian power in the current context.

\section{Russia in the International System}

\subsection{Historical context}

Contributions To understand the current situation in Russia and its status in the International System, we need to make an incursion in the history of Russia and present a few important events from the last two decades. Russia was one of the two superpowers of the Cold War world until 1991. In the 70s Brejnev was dreaming about the creation of an international socialist system that could replace the capitalist one. In the $80 \mathrm{~s}$ the weakness of the Soviet Union and its leadership became obvious and even though Mikhail Gorbachev made efforts to reform the economy, political system and external and security policy, the result was the dissolution of 
the Soviet Union in $1991^{1}$. The Russian population was tired of supporting the poor regions of the union and requested the reform and modernization of Russia. The causes of the dissolution were internal: the inefficiency of the planned economy, the lack of freedom, corruption and bureaucracy. The Russian federation was the main successor of the USSR, inheriting the Union's place in the major institutions and international forums, but its role and prestige were in a free fall in the 90s. The Russian policy objectives were not clearly developed and the responsible institutions were poorly managed ${ }^{2}$. The internal situation and the poor condition of the economy conducted Russia in an economic crisis in 1998.

Between 2000 and 2001, the government elite changed in Russia and the terrorist attack on September 11 brought back the country in the centre of the global issues ${ }^{3}$. The weak years of Russia were over and it was retransformed into a major partner of the developed world in the new security challenges. The new president of the Russian Federation, Vladimir Putin was seen as "a messenger of God" who will restore the order. The moment when Putin came to power coincided with an increase in the export prices of fuel and gas and the Russian population considered the wealth and prosperity of the country as his merits. From the beginning Putin affirmed the main objective of his external policy: restoring Russia`s role of great power in the international system and this objective can also be seen in his external policy today. The dissolution of the Soviet Union was seen by Mr. Putin as a geopolitical catastrophe of the $20^{\text {th }}$ century and in the first decade of the $21^{\text {st }}$ century showed that Russia wasn't ready to give up her annexation objectives. In 2008, president Medvedev`s external policy principles included the right of the country to protect Russians wherever they are and to intervene on their behalf. Based on this principles the Russians invaded Georgia in august 2008. The country`s actions at the beginning of the $21^{\text {st }}$ century were perceived as an intention to reconquer the lost empire and Putin's policy is seen as expansionist.

\subsection{The economic crisis and current situation in Russia}

Until the economic crisis of 2008, Russia managed to obtain high economic growth rates, stability and income growth. The Russian economy is based in a high percentage on natural resources as oil and gas and the increased price of these conducted to an impressive economic growth. The 2008 economic crises revealed the weakness of the Russian economy and in 2009 the Russian economic growth rate was negative. An Economist article from 2013 considers Russia's economy in "stagnation" because of the projected growth rate of $1.3 \%$ and highlights the need of investment in new technology, efficiency and labour productivity ${ }^{4}$. A World Bank report from March 2014 portrayed Russia in a confidence crisis that exposes economic weakness. In a low-risk scenario regarding the effects of the Crimean crisis, the report projected a 1.1\% economic growth rate in 2014 and $1.3 \%$ in 2015 . The main issue of the country's economy was the investors and consumers lack of confidence $^{5}$. In the table below we can see the effects of the global crisis on the GDP of the country and the effects of the confidence crisis after the Ukrainian and Crimean conflicts.

According to The World Bank Group the economic growth rate at the end of 2015 will be $-2.7 \%$. The Russian economy needs to be reformed and modernized and the best way for this to happen will be by foreign investments. However, the lack of liberal economy, corruption, inflation and the weak legal system are obstacles for the foreign investments. Also, president Putin's actions are unpredictable. The observers didn't aspect him to go ahead with the annexation of Crimea and his behaviour didn't predict his actions during the Ukrainian crisis. At the moment there are no perspectives regarding the Kremlin policy and the future of Russia is still unclear in terms of economic growth. Despite less encouraging data in recent years, Jim O'Neill in "The growth map"

\footnotetext{
${ }^{1}$ Roger E. KANET, Russia. Re-emerging great power, Basingstoke, Palgrave Macmillan, 2007, pp. 1-2.

${ }^{2}$ Ibidem, p. 2.

${ }^{3}$ Irina V. IsAKova, Russian governance in the twenty-first century. Geo-strategy, geopolitics and governance, London, Frank Cass, 2005, p. 1.

${ }^{4}$ THE ECONOMIST, ,The S word”, available online at http://www.economist.com/news/europe/21589455-will-stagnating-economy-bringabout-much-needed-structural-reform-s-word checked on: 17.06.2014.

${ }^{5}$ WORLD BANK Group, „Russia Economic Report. Confidence Crisis Exposes Economic Weakness”, available online at http://documents.worldbank.org/curated/en/2014/03/19357185/confidence-crisis-exposes-economic-weakness checked on: 18.09.2015.
} 
argues that Russia is a great emerging power based on the economic potential of the country and on the country's ability to generate high economic growth rates.

TABLE I: The Russian economic growth rate

\begin{tabular}{ll}
\hline \hline Year & $\begin{array}{l}\text { GDP } \\
\text { growth } \\
\text { rate }\end{array}$ \\
\hline 2008 & $5.2 \%$ \\
2009 & $-7,8 \%$ \\
2010 & $4.5 \%$ \\
2011 & $4.3 \%$ \\
2012 & $3.4 \%$ \\
2013 & $1.3 \%$ \\
2014 & $0.6 \%$ \\
2015 & $-2.7 \%$ \\
\hline \hline
\end{tabular}

This paper starts from presenting the current status of Russia, takes into consideration the actual vulnerabilities and will try to analyse the way these could be transformed into opportunities, so that Mr. Putin's foreign policy objective can be realized.

\section{Channels of power}

\subsection{BRICS}

Manuscript is accepted for review with the understanding that no substantial portion of the paper has been published The BRIC acronym was first mentioned by Jim O'Neill in his article "Building Better Global Economic BRICs" in November 2001. At the time he projected that the real GDP growth in large emerging economies will exceed that of the G7. The BRIC share in the world GDP was $8 \%$ in 2000 and according to the Goldman Sachs analyst by 2010 it should have been 14, 2\%. At the end of year 2000 the Chinese economy was already bigger than Italy's, one of the G7 countries. Jim O'Neill considered that at least 2 of the large emerging economies (China and India) should join the US, Japan, Germany, France and the UK in the G7 instead of Italy and Canada. He also predicted that Brazil will increase its GDP and will be close to the one of Italy ${ }^{6}$. In 2010, it actually overtook Italy, becoming one of the seventh largest economies in the world. Brazil, Russia, India and China managed to exceed Jim O'Neill's 2001 expectations, as he affirms "looking back, those earliest predictions, shocking to some at the time, now seem rather conservative"7. The total GDP of the four BRIC countries has close to quadrupled since 2001 and a third of the world growth came from the BRICs ${ }^{8}$.

In 2003, Dominic Wilson and Roopa Purushthaman, Goldman Sachs analysts, provided a new report regarding the future of emerging markets called "Dreaming with BRICs: The Path to 2050". The results of their report suggests that China's economy could be larger than the US one by 2041 and larger than everyone else`s as early as 2016. Also, India's economy could be larger than Japan's by 2032. By 2050, the G6 will look totally different than in 2003 and the sixth largest economies will be: China, US, India, Japan, Brazil and Russia. Some observers say that these projections are by far too optimistic and exaggerated. Either way, the results of the BRICS economies show the potential of growth these countries have and as the Goldman Sachs economists affirmed, if these economies will pursue sound policies and have the right conditions, these projections "might become reality, not just a dream"9?.

When we look at the economic growth rate of Russia, especially the 2015 estimation, the country's results seem different than of other's BRICS members that can still project much higher growth rates. However, Jim O'Neil explains the choice of Russia as one of the 4 largest emerging economies based on the potential of the country for projecting high economic growth rates. Starting 2009 the economic construct was transformed into a

\footnotetext{
${ }^{6}$ Jim O'NeILL, „Building Better Global Economic BRICs”, Global Economics Paper, 66, 2001.

${ }^{7} \mathrm{Jim}$ O'NeILL, The growth map. Economic opportunity in the BRICs and beyond, New York, Portfolio / Penguin, 2011 , p. 8.

${ }^{8}$ Ibidem, p. 8.

${ }^{9}$ Dominic Wilson şi Roopa Purushothaman, „Dreaming with BRICs: The Path to 2050”, Global Economics Paper, 99 , 2003 , pp. 34.
} 
political platform by Russia who invited the other countries to the first BRICs summit in Ekaterinburg. In 2011, South Africa was invited to join the emerging powers group and the BRIC becomes BRICS. From the first summit the countries purpose was to obtain a greater role in the formulation of international politics and in the main international institutions. Since 2009 the countries met annually and in 2014 decided to announce the first BRICS institution: The New Development Bank.

In 2014 Russia had to deal with the western economic sanctions and the western attempt to isolate Russia. For the first time in 16 years the Western countries and Japan met in Hague without Russia and refused to attend a G8 meeting in Moscow. The US president met in Hague with the Chinese president Xi Jinping and asked Beijing to remain at least neutral in the Crimean Crisis ${ }^{10}$. Despite of all the efforts made by the Western countries to isolate Russia, Mr. Putin managed to find in the BRICS group and the summer summits a way to prove to the world that his country isn't in isolation and at the same year's summit the group announced the first institution of the group: The new Development bank. Observers say that the group created the bank as an alternative to the Western dominated institutions: The World Bank and the International Monetary Fund. Others consider it a complementary institution. Vyacheslav Nikonov is the Chairman of the Russian National Committee for BRICS Studies and he believes that "amid the present principal disagreements with the USA and the EU over Ukraine and because G8 reformatting, Russia will develop increasingly closer ties with BRICS members and the countries of the Shanghai Cooperation Organization, as well as the Eurasian Economic Community with the participation of several former Soviet republics and other interregional organizations" Shortly after the annexation of Crimea, Russia signed a gas deal with China showing that the country is trying to decrease the country's dependence on the European Union's market. Also, the BRICS countries never opposed or condemned Russia for the annexation of Crimea and this was perceived as support by the country's leaders. Nikonov also declared that Russia wants to transform the BRICS into a respected international organization different than the European Union as it does not encroach upon anyone's sovereignty.

\subsection{The Eurasian Union}

In the centre of the foreign policy carried out by Mr. Putin is the extending and strengthening of the Eurasian Union. In 1995, Russia, Belarus and Kazakhstan signed an agreement concerning the formation of a custom union. From the beginning the observers saw this as Russia's way to reintegrate the former Soviet republics, even the ones in the EU's eastern neighbours. "Integration is no longer justified by past-oriented discourses about shared values and history but by economic pragmatism" 12 . The Eurasian Union was inspired and followed the model of the European Union, with focus on the economic advantages and not on the common history as in the EU. The Union became operational in January 1, 2015 and is composed by Russia, Belarus, Kazakhstan, Armenia and Kyrgyzstan. The physical headquarters of the Union is a "bureaucratic structure with a staff of 1000 housed in an eleven storey glass and steel building in Moscow"13.

Seen as an "artefact of Vladimir Putin's nostalgia for the Soviet Union, the Eurasian Union has been largely ignored in the West"14, until the Ukrainian crisis. In 2013, the president of Ukraine, Viktor Yanukovych under pressure from Russia, rejected the European Union trade association agreement. The people started protests against this decision and a conflict erupted between pro-Russian and pro-Europeans. With a population of fortyfive million people, Ukraine was supposed to be one of the most important country of the Eurasian Union. 80\% percent of the natural gas exported by Russia to European markets crosses through Ukrainian pipelines and the

\footnotetext{
${ }^{10}$ The GuARDIAN, „G7 countries snub Putin and refuse to attend planned G8 summit in Russia”, available online at http://www.theguardian.com/world/2014/mar/24/g7-countries-snub-putin-refuse-attend-g8-summit-russia checked on: 02.10.2015.

${ }^{11}$ RUSSIA AND INDIA REPORT, „BRICS oppose idea of unipolar world - Russian MP | Russia \& India Report”, available online at http://in.rbth.com/world/2014/03/29/brics_oppose_idea_of_uni-polar_world_russian_mp_34119.html checked on: 19.06.2014.

12 Dragneva, Rilka and Wolczuk, Kataryna, „Russia, the Eurasian Customs Union and the EU: Cooperation, Stagnation or Rivalry?”, available online at

https://www.chathamhouse.org/sites/files/chathamhouse/public/Research/Russia\%20and\%20Eurasia/0812bp_dragnevawolczuk.pdf checked on: 06.11.2015, p. 2.

${ }_{13}^{13}$ POPESCU NiCU, „Eurasian Union: the real, the imaginary and the likely”, Chaillot Paper, 132, 2014, p. 7.

${ }^{14}$ THE ECONOMIST, ,, The other EU”, available online at http://www.economist.com/news/europe/21613319-why-russia-backs-eurasianunion-other-eu checked on: 06.11.2015.
} 
country itself is a major market ${ }^{15}$. Russia claimed the Responsibility to Protect principle in the Ukrainian an Crimean crisis but most western countries considered the actions a wrong interpretation of the principle. The Western countries considered Russia's annexation of Crimea as a violation of International law and imposed economic sanctions to the country. The worsening economic situation and the anti-Russian sanctions have raised doubts about the sustainability of the new union.

After the recent events, many observers are pessimistic regarding the future of the Eurasian Economic Union. Russia wanted to regain its status of great power by reintegrating the former Soviet Union republics but the Ukrainian crisis worsened the situation. As Nicu Popescu affirms "Ukraine was supposed to be the crown jewel of a newly emerged, Russia-led Eurasia, but instead it turned into the graveyard of Moscow's ambitions to build a geopolitical Eurasia"16.

\section{Conclusions}

Russia is going through an economic and political crisis and the country's status of great power or even emerging power is contested. With a natural reserves dependent economy, the country needs reforms and modernization. The most appropriate way would be by attracting foreign investments, but the current crisis in Ukraine and the annexation of Crimea led to a confidence crisis. In this context, Russia is turning to the other emerging powers from the BRICS group and goes further with its Eurasian Union objectives.

Russia responded to the Western attempt of political isolations by intensifying its relations with the BRICS and in the BRICS. The emerging powers never condemned Russia for the annexation of Crimea and this was perceived as support by the country's leaders. Even though the BRICS isn't a natural construct and there are huge differences between the five member countries, they all have a common goal: to obtain a greater role in the main international institutions and in the formulation of international politics. The countries purpose is to change the western dominated international system and to counterbalance the current American hegemony. During the current crisis, BRICS proved it can be a useful tool for Russia, as the country couldn't be isolated.

An Economist article concludes by saying that Russia "wants not power so much as the appearance of power" 17 . Mr. Putin's dream was the Eurasian Economic Union despite its lack of benefits for Russia. The president wanted to resurrect the Soviet Union and to have influence in the former Soviet republics.

\section{Acknowledgements}

This work was possible due to financial support of the Sectoral Operational Programme for Human Resources Development 2007-2013, co-financed by the European Social Fund, under the project number POSDRU/159/1.5/S/155383, with the title "Quality, excellence, transnational mobility in doctoral research".

\section{References}

[1] Dragneva, Rilka And WolczuK, Kataryna, "Russia, the Eurasian Customs Union and the EU: Cooperation, Stagnation or Rivalry?", available online at https://www.chathamhouse.org/sites/files/chathamhouse/public/Research/Russia\%20and\%20Eurasia/0812bp_dragnev awolczuk.pdf checked on: 06.11.2015.

[2] Irina V. ISAKOVA, Russian governance in the twenty-first century. Geo-strategy, geopolitics and governance, London, Frank Cass, 2005.

[3] Roger E. KANET, Russia. Re-emerging great power, Basingstoke, Palgrave Macmillan, 2007.

[4] Robert MCMAHON, "Ukraine in Crisis", available online at http:/www.cfr.org/ukraine/ukraine-crisis/p32540 checked on: 06.11.2015.

\footnotetext{
${ }_{15}^{15}$ Robert MCMAHON, „Ukraine in Crisis”, available online at http://www.cfr.org/ukraine/ukraine-crisis/p32540 checked on: 06.11 .2015$.

${ }^{16}$ POPESCU NicU, op. cit., p. 43.

17 THE ECONOMIST, op. cit.
} 
[5] Jim O'NeILL, "Building Better Global Economic BRICs", Global Economics Paper, 66, 2001, pp. 1-15.

[6] Jim O'NeILL, The growth map. Economic opportunity in the BRICs and beyond, New York, Portfolio / Penguin, 2011.

[7] POPESCU NICU, "Eurasian Union: the real, the imaginary and the likely", Chaillot Paper, 132, 2014.

[8] RUSSIA AND INDIA REPORT, "BRICS oppose idea of unipolar world - Russian MP | Russia \& India Report", available online at http://in.rbth.com/world/2014/03/29/brics_oppose_idea_of_uni-polar_world_russian_mp_34119.html checked on: 19.06.2014.

[9] The ECONOMIST, "The S word", available online at http://www.economist.com/news/europe/21589455-willstagnating-economy-bring-about-much-needed-structural-reform-s-word checked on: 17.06.2014.

[10] THE ECONOMIST, "The other EU", available online at http://www.economist.com/news/europe/21613319-why-russiabacks-eurasian-union-other-eu checked on: 06.11.2015.

[11] The Guardian, "G7 countries snub Putin and refuse to attend planned G8 summit in Russia", available online at http://www.theguardian.com/world/2014/mar/24/g7-countries-snub-putin-refuse-attend-g8-summit-russia checked on: 02.10.2015.

[12] Dominic Wilson și Roopa Purushothaman, "Dreaming with BRICs: The Path to 2050", Global Economics Paper, 99, 2003.

[13] World Bank Group, "Russia Economic Report. Confidence Crisis Exposes Economic Weakness", available online at http://documents.worldbank.org/curated/en/2014/03/19357185/confidence-crisis-exposes-economic-weakness checked on: 18.06.2014. 